\title{
Fatty Acids of CLA-Enriched Egg Yolks Can Induce Transcriptional Activation of Peroxisome Proliferator-Activated Receptors in MCF-7 Breast Cancer Cells
}

\author{
Aneta A. Koronowicz, ${ }^{1}$ Paula Banks, ${ }^{1}$ Adam Master, ${ }^{2}$ Dominik Domagała, ${ }^{1}$ \\ Ewelina Piasna-Słupecka, ${ }^{1}$ Mariola Drozdowska, ${ }^{1}$ Elżbieta Sikora, ${ }^{1}$ and Piotr Laidler ${ }^{3}$ \\ ${ }^{1}$ Department of Human Nutrition, Faculty of Food Technology, University of Agriculture in Krakow, Balicka 122, \\ 30-149 Krakow, Poland \\ ${ }^{2}$ Department of Biochemistry and Molecular Biology, Medical Centre for Postgraduate Education, Marymoncka 99, \\ 01-813 Warsaw, Poland \\ ${ }^{3}$ Department of Medical Biochemistry, Jagiellonian University Medical College, Kopernika 7, 31-034 Krakow, Poland
}

Correspondence should be addressed to Aneta A. Koronowicz; aneta.koronowicz@gmail.com

Received 21 October 2016; Revised 2 February 2017; Accepted 12 February 2017; Published 26 March 2017

Academic Editor: Daniele Fanale

Copyright (C) 2017 Aneta A. Koronowicz et al. This is an open access article distributed under the Creative Commons Attribution License, which permits unrestricted use, distribution, and reproduction in any medium, provided the original work is properly cited.

In our previous study, we showed that fatty acids from CLA-enriched egg yolks (EFA-CLA) reduced the proliferation of breast cancer cells; however, the molecular mechanisms of their action remain unknown. In the current study, we used MCF-7 breast cancer cell line to determine the effect of EFA-CLA, as potential ligands for peroxisome proliferator-activated receptors (PPARs), on identified in silico PPAR-responsive genes: BCAR3, TCF20, WT1, ZNF621, and THRB (transcript TR $\beta 2$ ). Our results showed that EFA-CLA act as PPAR ligands with agonistic activity for all PPAR isoforms, with the highest specificity towards PPAR $\gamma$. In conclusion, we propose that EFA-CLA-mediated regulation of PPAR-responsive genes is most likely facilitated by cis9, trans11CLA isomer incorporated in egg yolk. Notably, EFA-CLA activated PPAR more efficiently than nonenriched FA as well as synthetic CLA isomers. We also propose that this regulation, at least in part, can be responsible for the observed reduction in the proliferation of MCF-7 cells treated with EFA-CLA.

\section{Introduction}

Peroxisome proliferator-activated receptors (PPARs) are ligand-activated transcription factors. Various fatty acids and their metabolic derivatives act as natural ligands for PPARs [1]. Some, including linoleic, linolenic, and arachidonic acid, were found to activate PPARs even at micromolar, physiologically relevant concentrations [2]. Hydroxyoctadecadienoic acids (HODEs), products of linoleic acid oxidation as well as arachidonic acid metabolite 15d-PGJ2 (15-deoxyprostaglandin J2), were also associated with PPAR activation $[3,4]$.

It has been suggested that ligand-dependent activation of PPARs results in the inhibition of proliferation in some model cancer cell lines [5-7]. In particular, PPAR $\gamma$ isoform was shown to reduce cancer cell proliferation as well as regulate cell differentiation, activate apoptosis, and inhibit angiogenesis [8-10]. Specifically, the administration of specific PPAR $\gamma$ agonist resulted in cells arrest in G1 phase and inhibited proliferation [5, 11]. However, available literature presents also contradicting results. In some studies, PPAR $\gamma$ specific antagonist, T0070907, significantly reduced proliferation and migration of breast cancer cells $[12,13]$.

Conjugated linoleic acid (CLA) term includes several isomers of linoleic acid, with two main isomers: cis9, trans11 (80-90\% of total CLA) and trans10,cis12. Available literature shows that CLA acts as a potent PPARs ligand and is involved in modulating lipid metabolism through PPAR-mediated 
pathways [14]. However, data showed isomer-specific activity of CLA; specifically, cis9, trans11 was characterized as PPAR agonist $[15,16]$ while trans10,cis12 was shown to inhibit the activity of synthetic PPAR agonists [15]. In addition, studies showed potential antitumor properties of cis9, trans11 [17-20] while the opposite effect was observed for trans10, cis12 isomer [18].

PPARs act as transcription factors and regulate the expression of dependent genes by binding to their PPREs. A significant number of genes regulated by PPARs have been described; however, the list is not exhaustive and is constantly being updated as new results are being published from both experimental data and bioinformatics analyses of promoter regions and PPRE consensus sequences. In the current study, we applied those tools to identify in silico PPRE selected genes involved in cell cycle progression and proliferation. Next, we analyzed the effect of synthetic cis9, trans11CLA and trans10,cis12CLA isomers as well as a mixture of fatty acids extracted from CLA-enriched and nonenriched egg yolk on the expression of those genes. To the best of our knowledge, our study is the first to address the effect of CLA incorporated in fatty acids profile of the egg yolk; we expect that activity of CLA in such a "bioorganic" form may deviate from that of a synthetic form. The presence of other fatty acids in an egg yolk, which themselves can act as potential ligands for PPARs, may modulate the action of CLA; therefore, our data may be particularly important for the evaluation of CLA-enriched food products.

\section{Materials and Methods}

2.1. Production of CLA-Enriched Egg Yolks. Production of CLAenriched egg yolks was performed in the National Research Institute of Animal Production in Krakow (Poland), as per the recommendations of the Local Animal Ethics Committee (approval number: 851/2011) as described previously [21]. Eggs were collected and stored at $4^{\circ} \mathrm{C}$, and yolks were separated from albumen, homogenized, and frozen at $-20^{\circ} \mathrm{C}$. Samples were then lyophilized and again stored at $-20^{\circ} \mathrm{C}$ until further analyses.

\subsection{Extraction and Analysis of Fatty Acids Composition.} Lipids from control and CLA-enriched yolks were extracted by using modified Folch method [22] as described previously [23]. $10 \mathrm{mg}$ of each lipid extract was subjected to saponification with $0.5 \mathrm{M} \mathrm{KOH} /$ methanol followed by methylation with $14 \%(\mathrm{v} / \mathrm{v}) \mathrm{BF} 3 /$ methanol and extraction with hexane. Fatty acid methyl esters (FAME) were analyzed by GC/MS as described previously [23].

2.3. CLA Isomers and Agonists/Antagonists of PPAR. cis9,trans11CLA and trans10,cis12CLA isomers (Nu-Chek Prep, USA) were dissolved in ethanol and stored under nitrogen in $-20^{\circ} \mathrm{C}$ and were introduced to cell cultures at final concentrations corresponding to their concentration in CLA-enriched egg yolk: cis9,trans11 at $30 \mu \mathrm{M}$ and trans10, cis 12 at $12 \mu \mathrm{M}$.

The synthetic agonists and antagonists for PPAR $\alpha$ (WY14643 and GW-6471), PPAR $\delta$ (GW-0742 and GSK0660), and PPAR $\gamma$ (pioglitazone (PIO), troglitazone, and T0070907) were prepared as per appropriate protocols of the manufacturer. Respective concentrations were selected based on their EC/IC50 characteristics and confirmed for MCF-7 cell line using Cytotoxicity LDH Test (Roche, Poland).

2.4. Cell Cultures. The human breast adenocarcinoma cell line MCF-7 (ATCC ${ }^{\circledR}$ HTB22TM) was purchased from the American Type Culture Collections. Cells were cultured in appropriate medium (Sigma-Aldrich, MO, USA) as per the ATCC protocol with the addition of $10 \%$ FBS (Sigma-Aldrich, MO, USA).

Cell viability was determined by Crystal Violet Assay (Sigma-Aldrich, MO, USA).

2.5. Fatty Acid Treatment. The experimental medium contained MEM supplemented with 10\% FBS and appropriate treatment: (a) fatty acids extract at $0.5 \mathrm{mg} / \mathrm{mL}$ from CLA-enriched egg yolks (EFA-CLA), (b) fatty acids extract at $0.5 \mathrm{mg} / \mathrm{mL}$ from nonenriched egg yolks (EFA), (c) cis9, trans11 synthetic isomer (final concentration at $35 \mu \mathrm{M}$ ), (d) trans10,cis12 synthetic isomer (final concentration at $13 \mu \mathrm{M}$ ), (e) untreated cell control (empty control, EC), and (f) negative control (NC; ethanol at final concentration $0.1 \%)$. Synthetic PPARs agonists and antagonist were used as positive controls for PPAR $\alpha(10 \mu \mathrm{M}$ WY14643 and $10 \mu \mathrm{M}$ GW-6471), PPAR $\delta(2 \mu \mathrm{M}$ GW-0742 and $1 \mu \mathrm{M}$ GSK0660), and PPAR $\gamma(40 \mu \mathrm{M}$ PIO, $10 \mu \mathrm{M}$ troglitazone, and $10 \mu \mathrm{M}$ T0070907). Each treatment included 3 biological and 3 technical replicates.

2.6. Plasmids. PPAR expression vectors were prepared using Gateway ${ }^{\circledR}$ Cloning System (Thermo Fisher, USA). Briefly, PPARA (CR456547_1), PPARD (NM_006238.4), and PPARG (NM_015869.4) ORF sequences were synthesized, optimized for the expression in human cells, and cloned into the pDONR221 Entry Vectors (GeneArt, Thermo Fisher, USA). Subsequently, the ORF inserts were transferred into pcDNA6.2/N-EmGFP-DEST Destination Vectors (Thermo Fisher, USA) under the CMV promoter control via Clonase II Recombination Reaction.

2.7. Cell Transfection with PPAR Encoding Plasmids. Cell lines with PPARA, PPARD, and PPARG overexpression were obtained via transient transfections with pcDNA6.2/NEmGFP-DEST vectors containing respective human PPAR ORF. MCF-7 cells were seeded on 12 -well plates, at $1 \times$ $10^{5}$ cells per well. $24 \mathrm{~h}$ after seeding, cells were transiently transfected with $1.5 \mu \mathrm{g}$ of PPAR encoding plasmids using Lipofectamine (Thermo Fisher Scientific, MA, USA) in OPTI-MEM medium (Thermo Fisher Scientific, MA, USA). $24 \mathrm{~h}$ after transfection, the growth medium was replaced with selective MEM medium with $10 \%$ FBS and $5.0 \mu \mathrm{g} / \mathrm{mL}$ blasticidin (BioShop, Canada). Transfected cells were cultured until confluency.

Real-time PCR and western blot method were performed to confirm the presence of PPAR plasmids after transfection (Figure S1 and Table S2, Supplementary Material available online at https://doi.org/10.1155/2017/2865283). 
2.8. Transfection with PPRE Plasmid. Cell lines overexpressing, respectively, PPARA, PPARD, and PPARG were seeded on the 12 -well plates, at $1 \times 10^{5}$ cells per well. After 24 hours, cells were transfected with $0.7 \mu \mathrm{g}$ X3 PPRE-TKluc plasmid (Cat. \# 1015, Addgene, USA) and $0.7 \mu \mathrm{g} p R L$ control (Cat. \# E2261, Promega, WI, USA) using Lipofectamine (Thermo Fisher Scientific, MA, USA) in OPTI-MEM medium (Thermo Fisher Scientific, MA, USA).

2.9. Dual-Luciferase Assay. 24 hours after transfection with PPRE plasmid, the medium was again replaced with MEM medium containing 10\% FBS and appropriate experimental treatment as described above. 24 hours after treatment, cells were harvested for isolation of protein luciferase.

The luciferase protein (Photinus pyralis and Renilla reniformis) detection was performed using Dual-Luciferase ${ }^{\circledR}$ Reporter Assay System (Promega, WI, USA) in GloMax ${ }^{\circledR}$ 20/20 Single Tube Luminometer (Promega, WI, USA), according to the manufacturer's instructions.

2.10. In Silico Selection and Experimental Confirmation of PPAR-Dependent Genes (PPAR-Responsive mRNAs). PPARresponsive genes were selected in silico by searching for peroxisome proliferator hormone response elements (PPREs, AGGTCANAGGTCA) within promoters and/or $5^{\prime}$ cis-regulatory regions of the promoters of genes involved in cell cycle progression and proliferation. This search was performed with NCBI Gene and Blast tools.

Experimentally, 24 hours after transfection with respective PPAR plasmids, the medium was replaced with MEM medium containing 10\% FBS and appropriate experimental treatment as described above. 48 hours after treatment, cells were harvested for mRNA isolation and RT-qPCR.

2.11. RNA Isolation, cDNA Synthesis, and RT-qPCR Analysis. Total RNA was isolated from the cells using RNA isolation kit for cell cultures (A\&A Biotechnology, Poland). Reverse transcription was performed on $1 \mu \mathrm{g}$ of total RNA using Maxima First-Strand cDNA Synthesis kit for RT-qPCR (Thermo Scientific, MA, USA). Quantitative verification of genes was performed using CFX96 Touch $^{\mathrm{TM}}$ Real-Time PCR Detection System instrument (Bio-Rad, CA, USA) and SYBR Green Precision Melt Supermix kit (Bio-Rad, CA, USA). Conditions of individual PCR reactions were optimized for given pair of oligonucleotide primers (Table S1, Supplementary Material). Basic conditions were as follows: $95^{\circ} \mathrm{C}$ for $10 \mathrm{~min}, 45 \mathrm{PCR}$ cycles at $95^{\circ} \mathrm{C}, 15 \mathrm{~s} ; 59^{\circ} \mathrm{C}, 15 \mathrm{~s} ; 72^{\circ} \mathrm{C}, 15 \mathrm{~s}$, followed by melting curve analysis $\left(65-97^{\circ} \mathrm{C}\right.$ with $0.11^{\circ} \mathrm{C}$ ramp rate and 5 acquisitions per $1^{\circ} \mathrm{C}$ ). Results were normalized using at least two reference genes (GAPDH, HPRT1, ACTB, or HSP90AB1) and were calculated using the $2^{-\Delta \Delta C}$ T method [24].

2.12. Protein Isolation and Western Blot Analysis. Cell lysis was carried out using Cell Lysis Buffer (Cell Signaling Technology, MA, USA) as per the manufacturer's protocol. Total protein quantification was performed using Pierce $B C A^{\mathrm{TM}}$ Protein Assay Kit (Thermo Fisher Scientific, MA, USA).

Each western blot followed a similar procedure. Protein extract was separated on a polyacrylamide gel and

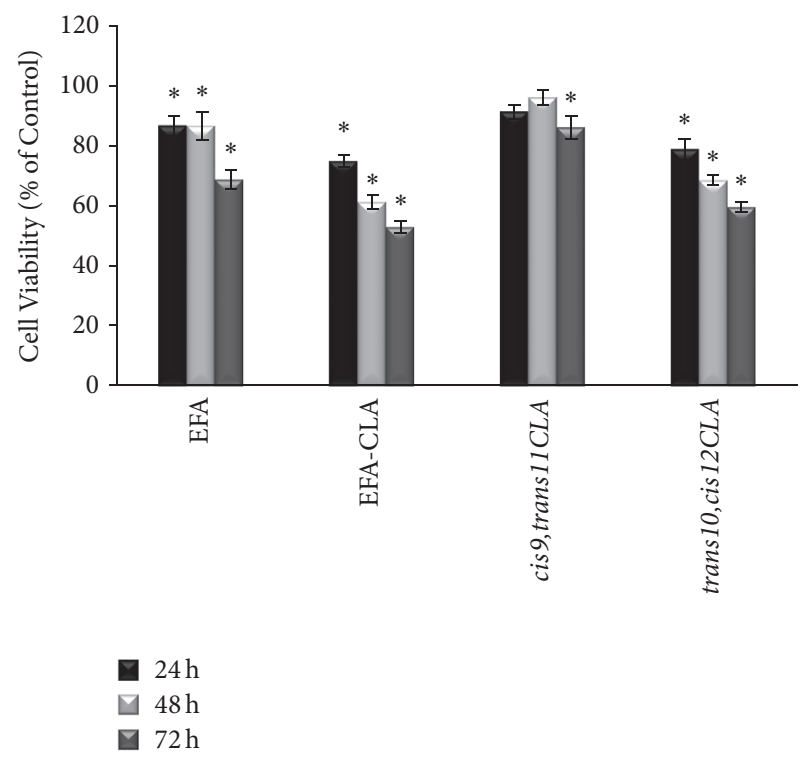

FIGURE 1: Effect of fatty acids on MCF-7 cells viability. Values are expressed as means \pm SD for $N \geq 9$, standardized to control (NC) as $100 \%$. Statistical significance was based on $t$-test; ${ }^{*} p<0.05$ versus control.

transferred to a nitrocellulose filter (Bio-Rad, CA, USA) by wet electroblotting. Subsequently, the immobilized proteins were incubated with appropriate primary antibody, specific for PPAR $\alpha$ (SAB2101852), PPAR $\gamma$ (SAB2101853), and PPAR $\delta$ (AV32880) as well as for selected in silico WT1 (SAB2102716), THRB (AV36994), and TCF20 (SAB2106444) from SigmaAldrich, MO, USA, or $\beta$-actin (\#8457) or $\beta$-tubulin (\#2128) from Cell Signaling Technology, MA, USA. Finally, appropriate secondary antibody conjugated with horseradish peroxidase (\#7074, Cell Signaling Technology, MA, USA) was applied. Detection was executed by chemiluminescence, using Clarity ${ }^{\mathrm{TM}}$ Western ECL Substrate (Bio-Rad, CA, USA). To remove the antibodies from the membrane, we used western blot stripping buffer (Thermo Scientific, MA, USA).

2.13. Statistical Analysis. All experiments were performed at least three independent times and measured in triplicate. Shapiro-Wilk's test was applied to assess normality of distribution. An independent samples $t$-test was applied to compare unpaired means between two groups. $p<0.05$ was considered statistically significant. All analyses were performed using Statistica ver.12 (StatSoft, Tulsa, OK, USA).

\section{Results}

3.1. Cell Viability. Treatment with both extracts, EFA and EFA-CLA, decreased viability of MCF-7 breast cancer cell line compared to the control; however, the effect of EFA-CLA was more evident compared to EFA. $72 \mathrm{~h}$ after treatment, cell viability in EFA-CLA-treated group decreased by $50 \%$ while for EFA the decrease in viability reached $32 \%$ (Figure 1). Treatment with synthetic trans10,cis12CLA reduced cell viability in a linear manner with incubation time, reaching $43 \%$ 

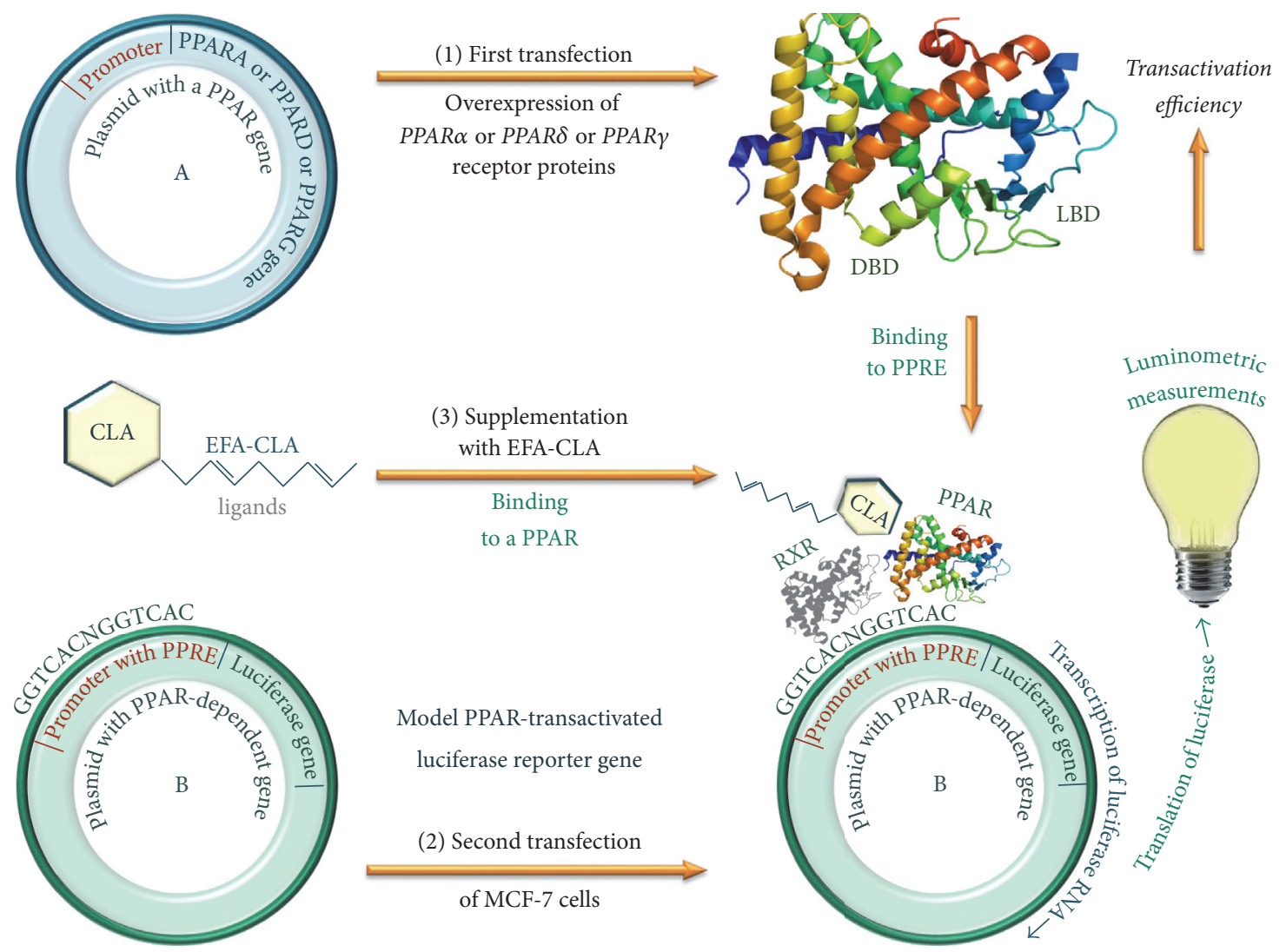

FIGURE 2: Experimental mechanism for studying the activity of EFA-CLA as a ligand for PPAR. DBD: DNA-binding domain specific for PPRE sequence in promoter regions of genes regulated by PPAR; LBD: ligand-binding domain (e.g., EFA-CLA).

at $72 \mathrm{~h}$. The reductive effect of cis9, trans11CLA isomer was less evident and statistically significant only after $72 \mathrm{~h}$ (overall reduction in viability by $15 \%)$.

\subsection{Effects of EFA-CLA on Transcriptional Activity of PPARs.}

To analyze the activity and specificity of various CLAs as potential PPAR ligands, we applied the PPAR-dependent luciferase expression model (Figure 2). We used specific agonists and antagonists for each isoform of PPARs as positive controls. Our results confirmed the expected effects of selected agonists and antagonists (Figures 3(a)-3(c)). The effect of experimental FA extracts varied. Compared to the negative control, EFA-CLA significantly increased the activity of PPAR $\alpha(202 \%$ of NC; $p<0.05$; Figure 3(a)), PPAR $\delta$ (187.10\% of NC; $p<0.01$; Figure 3(b)), and PPAR $\gamma(353 \%$ of NC; $p<0.001$; Figure 3(c)). Compared to EFA extract, EFA-CLA also showed statistically significant activation of all PPAR isoforms (Figures 3(a)-3(c)). Synthetic cis9, trans11 isomer also activated significantly all PPARs, PPAR $\alpha(211 \%$ of NC; $p<0.05$; Figure 3(a)), PPAR $\delta$ (221.88\% of NC; $p<0.01$; Figure 3(b)), and PPAR $\gamma$ (237\% of NC; $p<0.01$; Figure 3(c)). trans10, cis12CLA isomer had little or no effect on the activation of PPAR $\alpha$ and PPAR $\delta$ (Figures 3(a) and $3(\mathrm{~b})$ ); however, it reduced the activity of PPAR $\gamma$ ( $85 \%$ of $\mathrm{NC}$; $p<0.05$; Figure 3(c)).
3.3. Selective Effect of FA on Transcriptional Activity of PPARs. The selective effects of the studied FA as potential PPAR ligands are shown in Figures 4(a)-4(d). EFA-CLA was determined to be the most specific for PPAR $\gamma$ (3.5-fold increase in activity, $p<0.001$; Figure $4(\mathrm{a}))$. EFA extract acted as an antagonist towards both $\operatorname{PPAR} \alpha$ and $\operatorname{PPAR} \delta$, while it exhibited only negligible agonist activity on PPAR $\delta$ (1.44fold increase in activity, $p>0.05$, Figure 4(b)). cis9, trans11 isomer showed agonist properties towards all PPAR isoforms, with the strongest effect on PPAR $\gamma$ (2.37-fold increase in activity, $p<0.005$; Figure 4(c)). trans10, cis12 isomer showed no significant effect on transactivation of both PPAR $\alpha$ and $\operatorname{PPAR} \delta(p>0.05$, Figure $4(\mathrm{~d}))$, while it showed an antagonist activity towards PPAR $\gamma(p<0.01$, Figure $4(d))$.

3.4. Prediction of Potential PPRE-Dependent Genes In Silico. The prediction of potential PPRE-responsive genes was performed in silico. NCBI database was searched for the presence of specific PPRE (peroxisome proliferator response element) consensus sequences (AGGTCAAAGGTCA, AGGTCAGAGGTCA, AGGTCACAGGTCA, or AGGTCATAGGTC$A)$ in the $5^{\prime}$ region of genes linked to oncogenesis and cell cycle (Figure 5). Seven genes were identified: BCAR3, LZTS, SLC5A1, TCF20, WT1, ZNF621, and THRB (transcript TR $\beta 2$ ), potentially regulated by PPARs (Table 1 ). THRB 


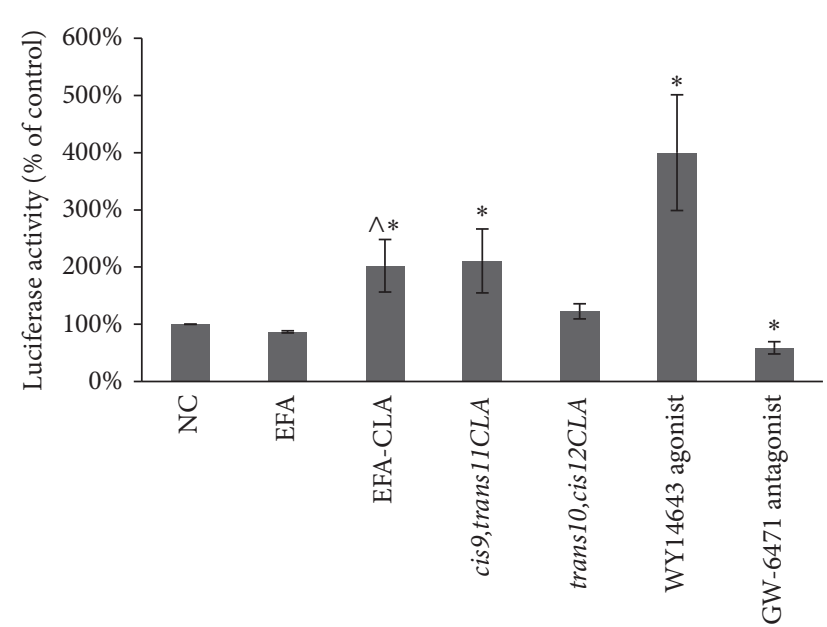

- PPAR $\alpha$

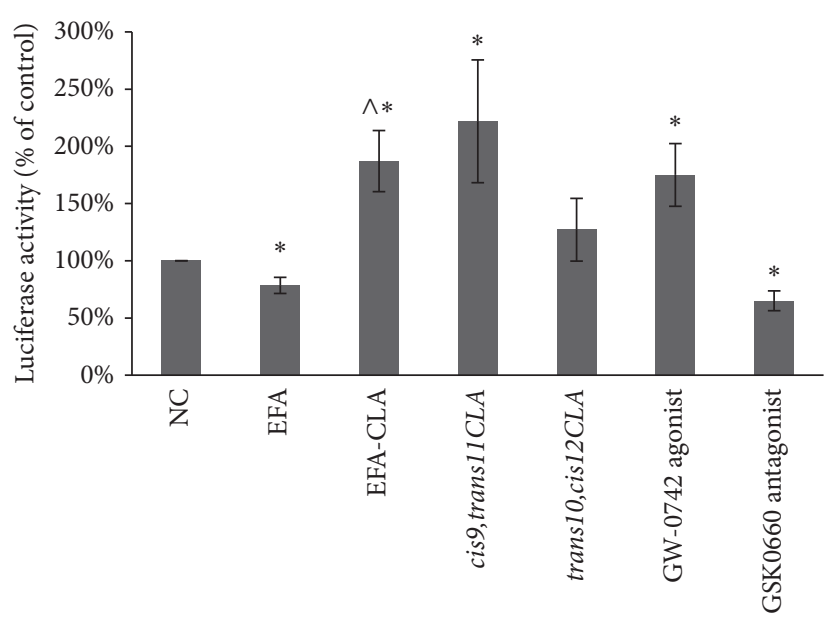

- PPAR $\delta$ (a)

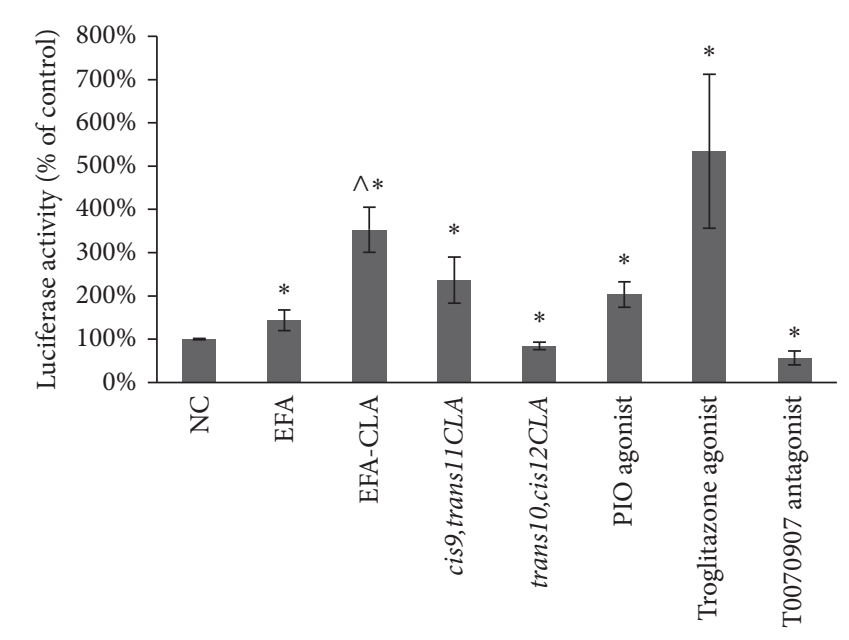

(b)

- PPAR $\gamma$

(c)

FIGURE 3: Effect of EFA-CLA on the activity of (a) PPAR $\alpha$, (b) PPAR $\delta$, and (c) PPAR $\gamma$ based on measured luciferase activity in dual-luciferase assay. Values are expressed as means \pm SEM for $N \geq 12$, standardized to control (NC) as $100 \%$. Statistical significance was based on $t$-test; ${ }^{*} p<0.05$ versus $N C$ or ${ }^{\wedge} p<0.05$ versus $E F A$.

TABLE 1: Identification of in silico putative PPAR-responsive genes.

\begin{tabular}{lccc}
\hline Gene symbol & Transcript & Position & NCBI reference sequence \\
\hline BCAR3 & AGGTCAGAGGTCA & $93663502-93663514$ & NC_000001.11 \\
LZTS1 & AGGTCAAAGGTCA & $20248971-20248983$ & NC_000008.11 \\
SLC5A1 & AGGTCACAGGTCA & $32033858-32033870$ & NC_000022.11 \\
TCF20 & AGGTCATAGGTCA & $42271609-42271621$ & NC_000022.11 \\
WT1 & AGGTCAGAGGTCA & $32470961-32470973$ & NC_000011.10 \\
ZNF621 & AGGTCAGAGGTCA & $32470822-32470834$ & NC_000003.12 \\
THRB $($ TR $\beta 2)$ & AGGTCACAGGTCA & $41052623-41052635$ & NC_000003.12 \\
\hline
\end{tabular}

BCAR3: breast cancer antiestrogen resistance 3; LZTS1: leucine zipper putative tumor suppressor 1; SLC5A: solute carrier family 5 member 1; TCF20: transcription factor 20; WT1: Wilms tumor 1; ZNF621: zinc finger protein 621; THRB: thyroid hormone receptor beta. 


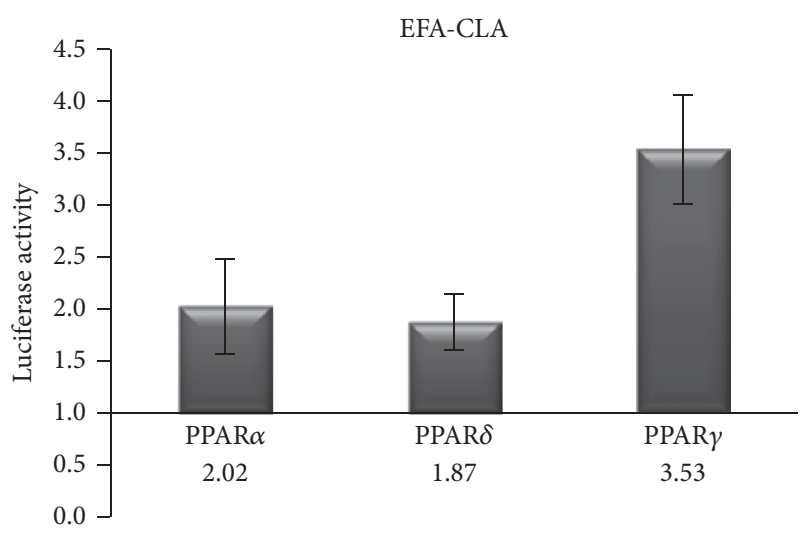

EFA-CLA

(a)

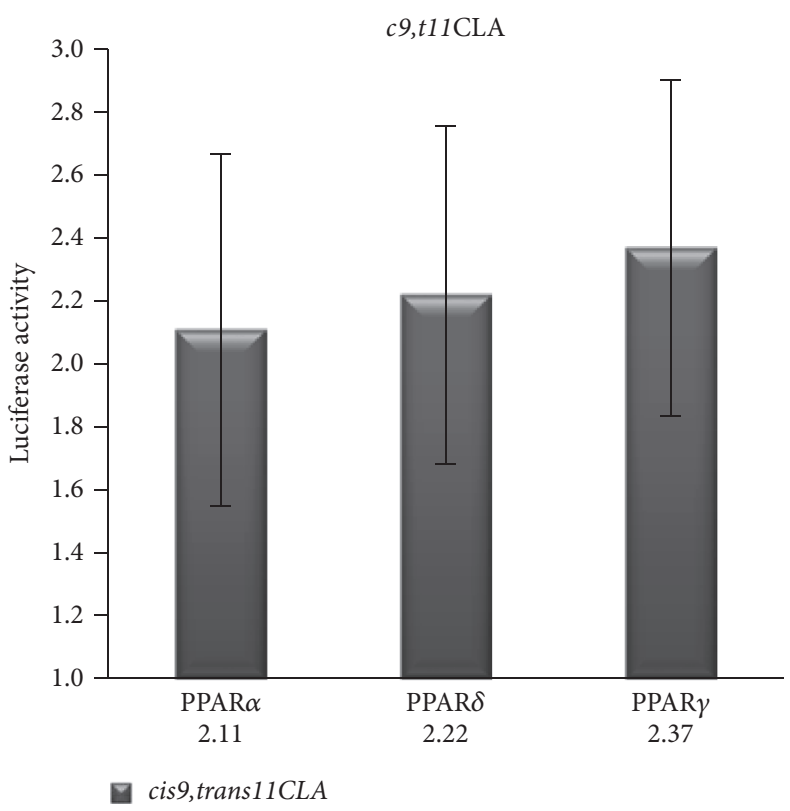

(c)

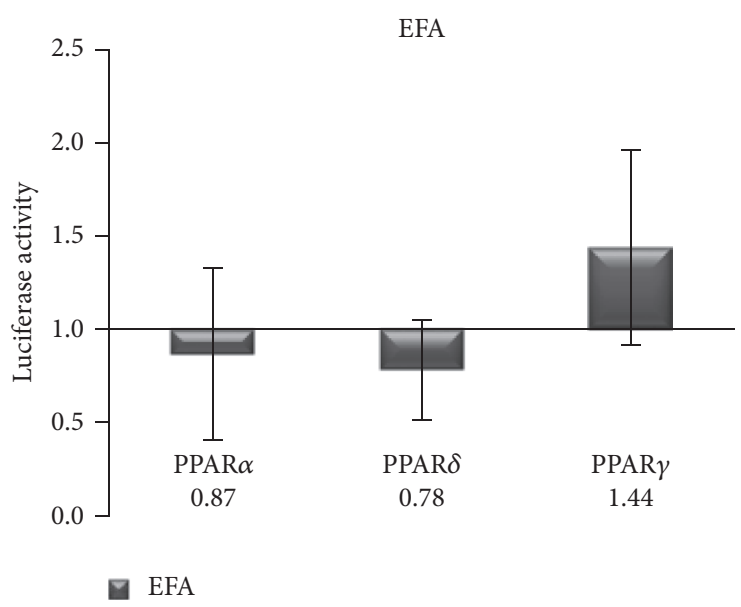

(b)

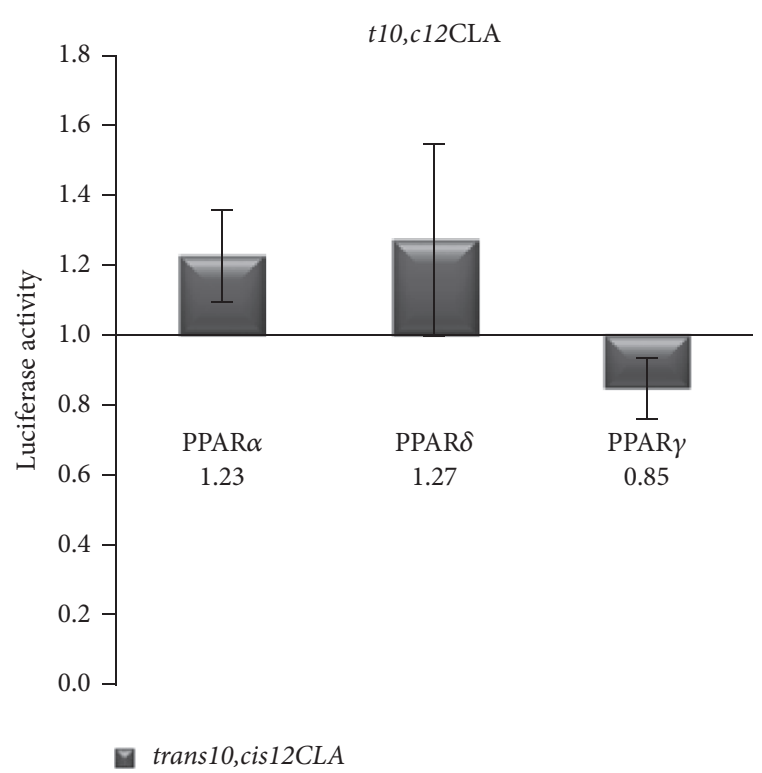

(d)

FIGURE 4: Selective effect of FA on PPARs expressed as fold difference versus control (100\%), based on data from Figure 3. Values are expressed as means \pm SEM for the $N \geq 12$.

gene was identified by the presence of the PPRE consensus sequence in a region of the alternative promoter for $\operatorname{TR} \beta 2$ isoform (intron between the 4th and 5th exon). Among identified potential PPRE-dependent genes, few were selected for further experimental analyses, including TCF20, WT1 ZNF621, and THRB.

3.5. Effects of EFA-CLA on the Expression of PPAR-Regulated Genes. Expression of selected PPAR-responsive genes (containing PPRE) has been tested in response to various experimental fatty acids as potential ligands for PPARA, PPARD, or PPARG. Our results showed both agonist and antagonist effects of studied experimental FA.
EFA-CLA added to the PPAR $\gamma$-overexpressing cells elevated the expression of TCF-20 over 3.2-fold and ZNF621 over 3.1-fold, while decreasing the expression of WT1 gene 1.2fold. However, the latest may be explained, at least in part, from the fact that WT1 gene is cotranscribed with interfering long, noncoding antisense RNA (WT1-AS) from the same bidirectional promoter. For cells overexpressing PPAR $\delta$, EFACLA treatment resulted in the elevated expression of TCF-20 over 3-fold, while for the PPAR $\alpha$-overexpressing cells ZNF621 gene was upregulated 1.8-fold.

The strongest enhancement of TCF-20 expression (over 13 -fold) was observed in PPAR $\gamma$ - and PPAR $\delta$-overexpressing cells after treatment with trans10,cis12CLA. Interestingly, the 


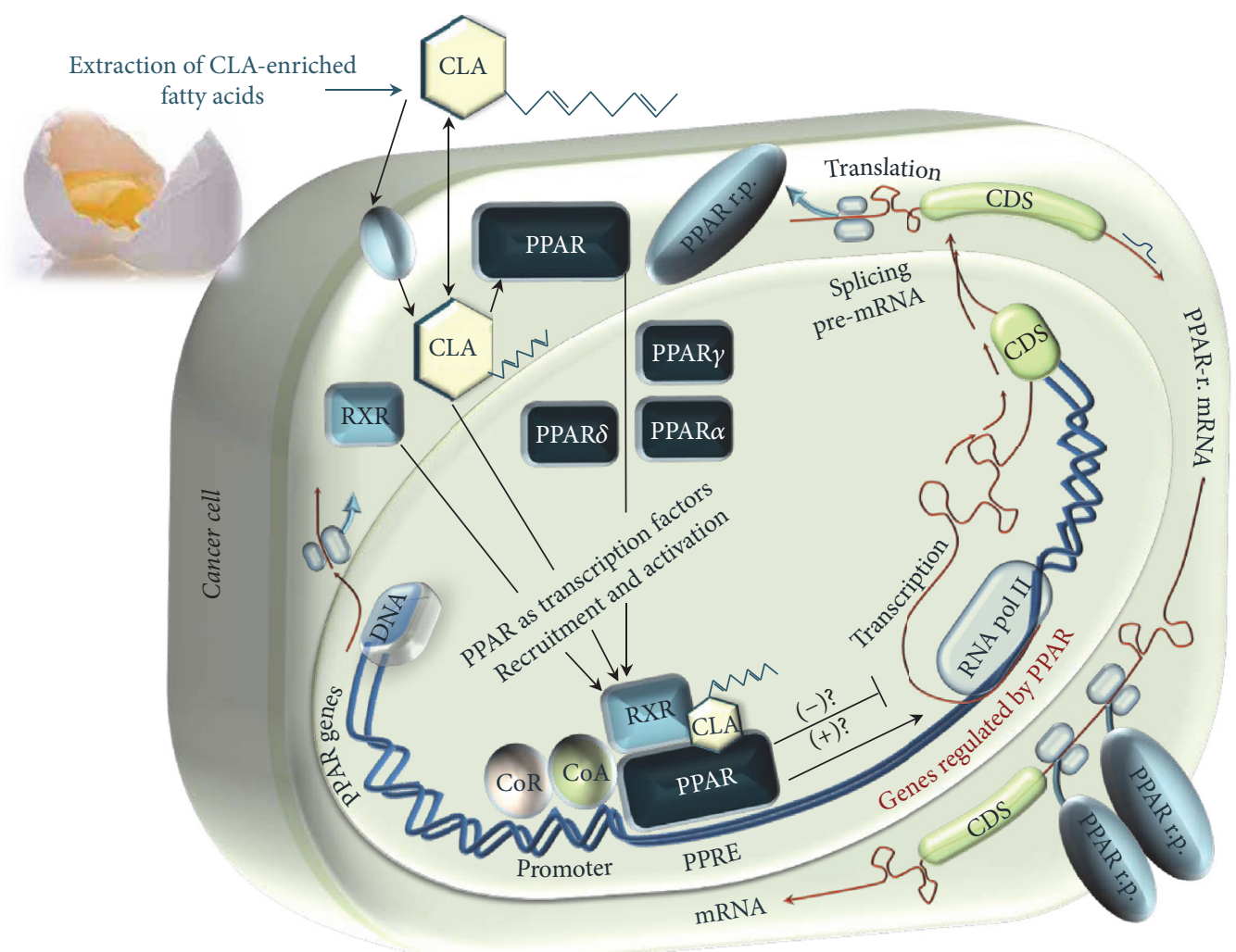

FIgURE 5: Molecular aspects of CLA-induced accumulation of PPAR-responsive transcripts. PPAR-r. mRNA: PPAR-regulated mRNAs; PPARr.p.: PPAR-regulated proteins; PPRE: peroxisome proliferator hormone response element (AGGTCANAGGTCA); RXR: retinoid X receptor; ORF: open reading frame (coding sequence).

expression of THRB (TR $\beta 2$ variant) gene was also strongly increased by the treatment with trans10, cis12CLA over 18.15-, 17.2-, and 7.9-fold in PPAR $\delta$-, PPAR $\gamma$-, and PPAR $\alpha-$ overexpressing cells, respectively, but not observed for EFACLA-treated cells. Those results show that the presence of other fatty acids in EFA-CLA mixture contributes to the overall effect of FA treatment.

It is clear that the expression of the selected genes (TCF20, WT1, ZNF621, and THRB), which were identified for the first time in this work as putative PPAR-responsive genes, was altered in the presence of the used agents (Table 2) and that among them TCF-20 was affected the most by EFA-CLA.

\section{Discussion}

Chicken egg enriched with conjugated linoleic acid (CLA) via feed modification meets the criteria of the functional food product. Based on Roberfroid's [25] classification, CLAenriched egg can be considered as a conventional food product that is intended to be consumed as a part of a normal diet but is modified to contain biologically active substances, that is, CLA isomers. It has been shown to have a beneficial effect on physiological functions of the human body, in a way that goes beyond its nutritional value, specifically by lowering the risk of developing atherosclerosis [26]. Our previous studies showed additional beneficial properties of CLAenriched eggs in reducing proliferation of breast cancer and melanoma cells $[23,27]$. The current manuscript supports those findings as our new results showed that fatty acids extract from CLA-enriched egg yolks (EFA-CLA) reduced the viability of MCF-7 breast cancer cell line (Figure 1). However, the molecular mechanism is not fully understood. Comparison of the effect on cancer cell proliferation between extracts from CLA-enriched and nonenriched egg yolks could lead to the conclusion that it is simply the result of the presence of CLA isomers incorporated in the egg yolk lipids. Available literature would support such a hypothesis as numerous studies showed an inhibitory effect, especially for cis9,trans11CLA isomer, on tumor cells [28-32]. Indeed, our analysis of FA profile of CLA-enriched egg yolk showed that cis9,trans11CLA was incorporated more efficiently $(3: 1$ ratio) than trans10,cis12 isomer [21] and therefore could predominate in EFA-CLA. Interestingly, comparison of the effect of synthetic CLA isomers with CLA-EFA from egg yolk showed the advantage of the latter in reducing cancer cell viability (Figure 1). The analysis of fatty acids profiles between enriched and nonenriched egg yolks revealed not only CLA incorporation but also unexpected, significant change in SFA/MUFA ratio, specifically an increase in total SFA concentration at the expense of MUFA. Thus, a question 


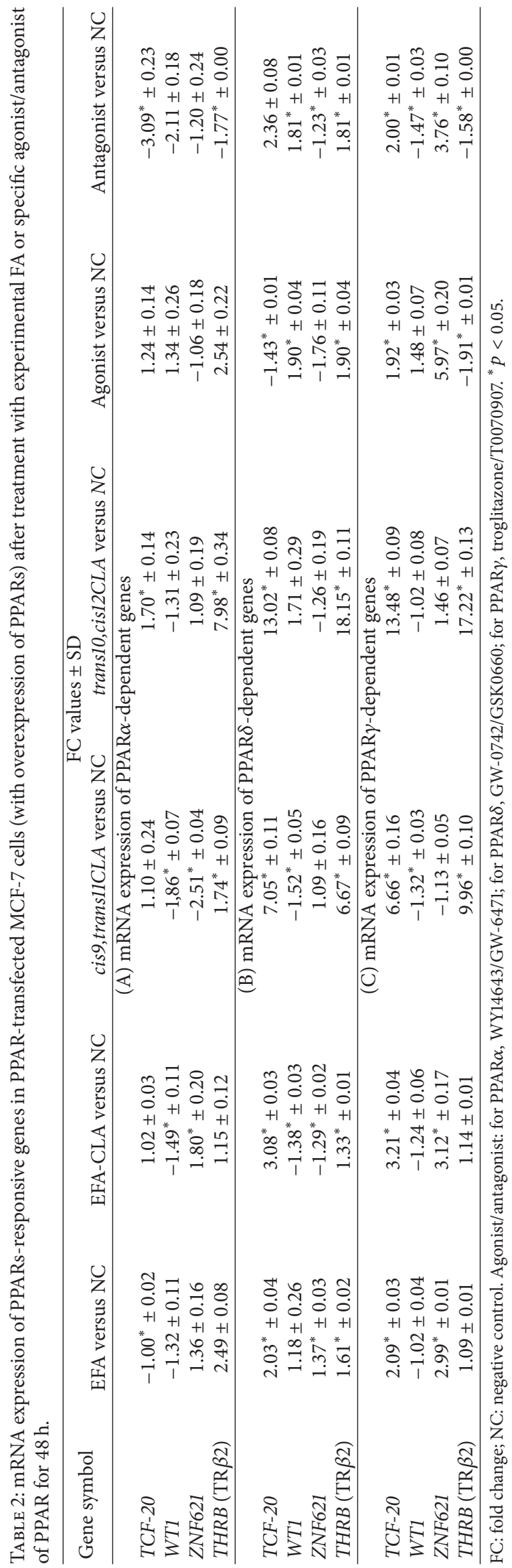


arises of whether it is an individual or combined effect of CLA and modified SFA/MUFA ratio in enriched egg yolks on MCF-7 cell line [23]. We observed that results of CLA-EFA are most likely achieved by the effect of both: incorporated CLA isomers and other fatty acids in eggs modified organically through hens' diet [23]; however, this issue requires further research.

It has been shown that PPAR agonists have different properties for individual PPAR isoforms, with different absorption and distinctive gene expression profiles. To our knowledge, this is the first study focused on the effect of FA from CLAenriched egg yolks on transcriptional activation of PPARs $(\operatorname{PPAR} \alpha, \operatorname{PPAR} \gamma$, and PPAR $\delta$ ). All experiments included as controls synthetic CLA isomers as well as standard agonists and antagonists of different PPARs. Our results showed that EFA-CLA extract exhibits the properties of agonists for all PPAR isoforms (Figures 3(a)-3(c)); however, those properties seem to be most selective towards PPAR $\gamma$ (Figure 4). Interestingly, PPAR $\gamma$ has been associated with the greatest impact on cancer cell proliferation, survival, and differentiation, and its ligands are associated with anticancer properties $[33,34]$. In addition, as observed for EFA-CLA, transactivation of PPAR receptors is more effective compared to fatty acids extracted from a nonenriched egg yolk (EFA) (Figures 3(a)-3(c)). Since cis9, trans11CLA isomer showed PPAR agonist activity (Figures 3(a)-3(c)) and since this isomer was 3-fold more efficiently incorporated into egg yolks than trans10, cis12CLA [23], it could be hypothesized that cis9, trans11CLA plays a significant role in EFA-CLA-mediated activation of PPARs.

The effect of synthetic CLA isomers provided us with important information about their specificity. While cis9, trans11 isomer acted as a PPAR agonist (Figures 3(a)-3(c)), the antagonist effect was observed for trans10,cis12 isomer, specifically on PPAR $\gamma$ (Figure 3(c)). Available literature is consistent with our results. cis9, trans11 isomer has been reported to inhibit cell growth $[15,16]$ showing antitumor properties [17-20]. It has been found as well that the presence of trans10,cis12 isomer may abrogate the antiproliferative activity of cis9,trans11 [18] and even inhibit the activity of synthetic PPAR agonists [15]. Thus, it is even more interesting that our results showed more efficient reduction in cancer cells proliferation for EFA-CLA treatment than using a pure synthetic cis9, trans11CLA isomer that may suggest other factors including modified SFA/MUFA ratio in enriched egg yolks [23], supporting antiproliferative action of cis9, trans11CLA isomer.

PPARs act as transcription factors and regulate the expression of dependent genes by binding to their PPREs. Available literature gives a number of genes regulated by PPARs; the ligand-dependent transcription factors [35] and the expression of those genes can be both inhibited or activated depending on the ligand, suggesting selectivity [36]. CLA isomers have been found to act as PPAR ligands and shown to be involved in the inhibition of transcription of genes including TNF [37], NFKB1 [38], and NR113 [39] as well as transactivation: TGFB1 [40], BRCA1 [41], PTEN [42], p21/WAF1/CDKN1A [43], CEBPA [44], ABCB4 [45], and AOX [46]. Although a significant number of genes regulated by PPARs have been described, the list is not exhaustive and is constantly updated as new results are being published from both experimental data and bioinformatics analyses of promoter regions containing PPRE consensus sequences (AGGTCANAGGTCA) (Figure 5).

In the current study, we applied bioinformatic tools to find genes with PPRE and analyze the effect of CLA on the expression of these genes. To our knowledge, we proposed several new genes that could be potentially PPARregulated: BCAR3, LZTS, SLC5A, TCF20, WT1, ZNF621, and THRB (transcript TR $\beta 2$ ) (Table 2). Since preliminary data showed that some of them were strongly regulated by PPARs, we studied the expression of TCF20, WT1, THRB (TR $\beta 2)$, and ZNF621 genes in the context of various PPAR ligands, including EFA-CLA.

First one TCF20 can act as a phosphoserine-specific repressor of estrogen receptors (ER) in estrogen-dependent tumors [47]. MCF-7 human breast carcinoma cell line is estrogen receptor (ER) positive; thus, the expression of TCF20 should inhibit ER and consequently impair the viability of the tumor cells. Our results confirm these assumptions, showing elevated TCF20 mRNA level in cells treated with EFA-CLA. This effect was much stronger than for EFA (Table 2). Interestingly, the most pronounced effect was found for trans10, cis12CLA isomer (Table 2), which may explain its advantages over the $c i s 9$, trans11CLA in reducing the viability of MCF-7 (positively correlates with its effect on the reduction in cell viability) (Figure 1). In contrast to Pariza et al. [18], this result also suggests that trans10,cis12CLA isomer could support antiproliferative action of cis9, trans11CLA in EFACLA via transcription-enhancing effects on TCF20.

Available literature addresses the relationship between receptors encoded by PPAR and THRB genes [48-50]. THRB encodes three isoforms of human thyroid hormone receptor: $\operatorname{TR} \beta 1$ and tissue-specific TR $\beta 2$ and TR $\beta 4$, which are thought to be engaged in cell cycle control and metabolism [51]. Recently, THRB has been studied as a tumor suppressor [52]. Although TR $\beta 1$ isoform has been found to play a role in the competitive inhibition of the PPAR transactivation [53], there is limited information on the relationships between TR $\beta 2$ and PPAR receptors. TR $\beta$ and PPAR receptors are linked by the same obligatory coreceptor, retinoid X receptor (RXR), that binds to their heterodimeric partners before binding to DNA. Although RXR plays a central role in regulating the activity of a number of nuclear hormone receptors including $\operatorname{TR} \beta$ and PPARs by acting as a heterodimeric partner, this receptor is known to be constitutively expressed in cells [53]; therefore, focusing on PPARs, we do not show the expression of RXR in this paper. Nevertheless, it has been reported that TR $\beta$ and PPAR receptors can compete for binding to RXRs in the nucleus [54]. Since we have found PPRE within the sequence of TR $\beta 2$-specific promoter, located in intron IV of THRB gene, the bidirectional regulation of TR $\beta 2$ and PPARs is thought to be more complex. Results presented in the current manuscript indicated enhanced transactivation of TR $\beta 2$ by all PPARs isoforms in response to the treatment with experimental FA (Table 2) that may be evidence of the functional activity of the TR $\beta 2$-specific PPRE; however, this needs further studies. The most significant effect was measured for the synthetic CLA isomers, especially 
trans10,cis12 (Table 2). Taken together, our findings showed that transcription levels of TR $\beta 2$ are elevated by PPARs and their agonists. Simultaneously, TR $\beta 1$ isoform has been shown to compete with PPAR for access to the RXR coreceptor or for PPRE binding sites in promoter regions of regulated genes [50] that could suggest TR $\beta 1$-mediated inhibitory role in expression of TR $\beta 2$ isoform and possibly other PPARresponsive genes.

WT1 gene, as a transcription factor, directly or indirectly interacts with a number of genes involved in cell cycle and neoplasia, including HIF1A, AREG, SRY, NROB1, SOX9, IGF2, MDM4, BRCA1, TP53, and SP1 (NCBI Gene). Available literature suggests an oncogenic nature of WT1 and has shown its overexpression in various tumors and tumor cell lines, especially in breast cancer cells and melanoma $[55,56]$. In addition, decreased levels of WT1 gene expression correlated with reduced cell proliferation in both melanoma and breast cancer cells $[57,58]$. WT1 has also been linked with malignant transformation in breast cancer, and its overexpression associated with reduced susceptibility to drug treatment. Indeed, it has been shown for estrogen-dependent lines that WT1 positively regulates the expression of EGFR and HER2 [55], contributing to the resistance to hormone therapy $[59,60]$. In melanoma, in vitro $W T 1$ silencing resulted in decreased cell proliferation, followed by apoptosis induction with caspase3 activation [61], while in vivo it reduced the melanoma metastatic to lungs [56]. On the other hand, some studies indicate that pharmacologic activation of PPAR $\delta$ by its agonists (GW0742 and GW501516) inhibited proliferation of the murine melanoma cells, accompanied by downregulation of $W T 1$ [62]. It was suggested that $\operatorname{PPAR} \delta$ can act via the PPRE in the WT1 promoter and directly suppress its activity; however, our results do not support this hypothesis. Although the use of a known $\operatorname{PPAR} \delta$ agonist, GW0742, resulted in PPAR $\delta$ activation (Figure 3(b)), no decrease in the expression of WT1 was measured (Table 1). This contradiction may result from the use of different biological materials suggesting cell/tissue-specific regulation and/or association/dissociation of different corepressors or coactivators to transcription machinery. Interestingly, we showed that treatment with EFACLA and cis9,trans11 reduced expression of WT1 via the activation of PPAR $\delta$ (Table 2). A similar effect was observed for other experimental FA (Table 2) suggesting that various PPAR ligands may exert different effects in different cells; however, this hypothesis should be studied.

\section{Conclusion}

In conclusion, potential tumor suppressor properties of PPAR receptors make their ligands attractive candidates for the development of new chemopreventive, anticancer agents. Here, we show for the first time a functional food product, CLA-enriched egg (EFA-CLA), that is more effective in reducing of MCF-7 cancer cells proliferation than synthetic CLA isomers. This EFA-CLA effect could result from the high content of cis9, trans11 isomer, altered SFA/MUFA ratio in enriched egg yolks, and/or supportive role of trans10,cis11 isomer in regulation of specific genes. Our results indicate that EFA-CLA can act as a ligand of PPARs, showing an agonist activity, specifically towards the PPAR $\gamma$ isoform. Control, synthetic cis9,trans11 isomer of CLA exerted an agonist effect on all PPAR receptors, while trans10,cis12 showed no effects or even acted as an antagonist of PPAR $\gamma$. However, this isomer was able to regulate some specific genes containing PPREs such as TCF20 involved in cell cycle arrest. Simultaneously, cis9, trans11 isomer upregulated THRB suppressor and downregulated WT1 oncogene showing a small part of a PPAR action that in case of EFA-CLA leads to the observed reduction in proliferation of the breast cancer cells. It seems therefore that CLA-enriched eggs could be considered as food products with anticancer potential.

\section{Conflicts of Interest}

The authors report no financial or other conflicts of interest relevant to the subject of this article.

\section{Acknowledgments}

This work was supported by the Polish National Science Center (Grant no. 2011/03/B/NZ9/01423) “Conjugated Linoleic Acid (CLA) Induced Transcriptional Activation of PPAR: An Investigation of Molecular Mechanisms of Putative Anticancer Action of Fatty Acids of CLA-Enriched Egg Yolks" and by the Ministry of Science and Education (Grant no. N N312 236038) “The Influence of CLA-Enriched Hen's Egg Yolk Lipids on the Proliferation of Selected Tumor Cell Lines.”

\section{References}

[1] B. Grygiel-Górniak, "Peroxisome proliferator-activated receptors and their ligands: nutritional and clinical implications-a review," Nutrition Journal, vol. 13, no. 1, article 17, 2014.

[2] G. Krey, O. Braissant, F. L’Horset et al., "Fatty acids, eicosanoids, and hypolipidemic agents identified as ligands of peroxisome proliferator-activated receptors by coactivator-dependent receptor ligand assay," Molecular Endocrinology, vol. 11, no. 6, pp. 779-791, 1997.

[3] L. Nagy, P. Tontonoz, J. G. A. Alvarez, H. Chen, and R. M. Evans, "Oxidized LDL regulates macrophage gene expression through ligand activation of PPAR $\gamma$," Cell, vol. 93, no. 2, pp. 229-240, 1998.

[4] S. A. Kliewer, J. M. Lenhard, T. M. Willson, I. Patel, D. C. Morris, and J. M. Lehmann, "A prostaglandin J2 metabolite binds peroxisome proliferator-activated receptor $\gamma$ and promotes adipocyte differentiation," Cell, vol. 83, no. 5, pp. 813-819, 1995.

[5] W. Motomura, T. Okumura, N. Takahashi, T. Obara, and Y. Kohgo, "Activation of peroxisome proliferator-activated receptor $\gamma$ by troglitazone inhibits cell growth through the increase of p2 $7^{\text {Kipl }}$ in human pancreatic carcinoma cells," Cancer Research, vol. 60, no. 19, pp. 5558-5564, 2000.

[6] M. Maggiora, M. Bologna, M. P. Cerù et al., "An overview of the effect of linoleic and conjugated-linoleic acids on the growth of several human tumor cell lines," International Journal of Cancer, vol. 112, no. 6, pp. 909-919, 2004.

[7] G. Martinasso, M. Oraldi, A. Trombetta et al., "Involvement of PPARs in cell proliferation and apoptosis in human colon cancer specimens and in normal and cancer cell lines," PPAR Research, Article ID 93416, 2007. 
[8] J. N. Feige, L. Gelman, C. Tudor, Y. Engelborghs, W. Wahli, and B. Desvergne, "Fluorescence imaging reveals the nuclear behavior of peroxisome proliferator-activated receptor/retinoid $\mathrm{X}$ receptor heterodimers in the absence and presence of ligand," Journal of Biological Chemistry, vol. 280, no. 18, pp. 17880-17890, 2005.

[9] A. Margeli, G. Kouraklis, and S. Theocharis, "Peroxisome proliferator activated receptor- $\gamma$ (PPAR- $\gamma$ ) ligands and angiogenesis," Angiogenesis, vol. 6, no. 3, pp. 165-169, 2003.

[10] S. Sethi, O. Ziouzenkova, H. Ni, D. D. Wagner, J. Plutzky, and T. N. Mayadas, "Oxidized omega-3 fatty acids in fish oil inhibit leukocyte-endothelial interactions through activation of PPAR $\alpha$, Blood, vol. 100, no. 4, pp. 1340-1346, 2002.

[11] H. Koga, S. Sakisaka, M. Harada et al., "Involvement of $\mathrm{p} 21^{\text {WAF1/Cip } 1}, \mathrm{p} 27^{\text {Kip } 1}$, and $\mathrm{p} 18^{I N K 4 c}$ in troglitazone-induced cellcycle arrest in human hepatoma cell lines," Hepatology, vol. 33, no. 5, pp. 1087-1097, 2001.

[12] Y. Y. Zaytseva, N. K. Wallis, R. C. Southard, and M. W. Kilgore, "The PPAR $\gamma$ antagonist T0070907 suppresses breast cancer cell proliferation and motility via both PPAR $\gamma$-dependent and independent mechanisms," Anticancer Research, vol. 31, no. 3, pp. 813-823, 2011.

[13] W. Lu, P. Che, Y. Zhang et al., "HL005-a new selective PPAR $\gamma$ antagonist specifically inhibits the proliferation of MCF-7," Journal of Steroid Biochemistry and Molecular Biology, vol. 124, no. 3-5, pp. 112-120, 2011.

[14] S. Y. Moya-Camarena, J. P. Vanden Heuvel, S. G. Blanchard, L. A. Leesnitzer, and M. A. Belury, "Conjugated linoleic acid is a potent naturally occurring ligand and activator of PPAR $\alpha$," Journal of Lipid Research, vol. 40, no. 8, pp. 1426-1433, 1999.

[15] J. R. Miller, P. Siripurkpong, J. Hawes, A. Majdalawieh, H.-S. Ro, and R. S. McLeod, "The trans-10, cis-12 isomer of conjugated linoleic acid decreases adiponectin assembly by PPAR $\gamma$ dependent and PPAR $\gamma$-independent mechanisms," Journal of Lipid Research, vol. 49, no. 3, pp. 550-562, 2008.

[16] Y. Yu, P. H. Correll, and J. P. V. Heuvel, "Conjugated linoleic acid decreases production of pro-inflammatory products in macrophages: evidence for a PPAR $\gamma$-dependent mechanism," Biochimica et Biophysica Acta-Molecular and Cell Biology of Lipids, vol. 1581, no. 3, pp. 89-99, 2002.

[17] M. F. McCarty, "Activation of PPARgamma may mediate a portion of the anticancer activity of conjugated linoleic acid," Medical Hypotheses, vol. 55, no. 3, pp. 187-188, 2000.

[18] M. W. Pariza, Y. Park, and M. E. Cook, "Mechanisms of action of conjugated linoleic acid: evidence and speculation," Proceedings of the Society for Experimental Biology and Medicine, vol. 223, no. 1, pp. 8-13, 2000.

[19] C. Ip, S. Banni, E. Angioni et al., "Conjugated linoleic acidenriched butter fat alters mammary gland morphogenesis and reduces cancer risk in rats," Journal of Nutrition, vol. 129, no. 12, pp. 2135-2142, 1999.

[20] M. M. Ip, P. A. Masso-Welch, S. F. Shoemaker, W. K. Shea-Eaton, and C. Ip, "Conjugated linoleic acid inhibits proliferation and induces apoptosis of normal rat mammary epithelial cells in primary culture," Experimental Cell Research, vol. 250, no. 1, pp. 22-34, 1999.

[21] A. A. Koronowicz, P. Banks, B. Szymczyk et al., "Dietary conjugated linoleic acid affects blood parameters, liver morphology and expression of selected hepatic genes in laying hens," British Poultry Science, vol. 57, no. 5, pp. 663-673, 2016.

[22] J. Folch, M. Lees, and G. H. Sloane Stanley, "A simple method for the isolation and purification of total lipides from animal tissues," The Journal of biological chemistry, vol. 226, no. 1, pp. 497-509, 1957.

[23] A. A. Koronowicz, P. Banks, D. Domagala, A. Master, D. Domagała et al., "Fatty acids extract from CLA-enriched egg yolks can mediate transcriptome reprogramming of MCF-7 cancer cells to prevent their growth and proliferation," Genes \& Nutrition, vol. 11, article 22, 2016.

[24] K. J. Livak and T. D. Schmittgen, "Analysis of relative gene expression data using real-time quantitative PCR and the $2^{-\Delta \Delta C_{\mathrm{T}}}$ method," Methods, vol. 25, no. 4, pp. 402-408, 2001.

[25] M. B. Roberfroid, "Global view on functional foods: European perspectives," The British Journal of Nutrition, vol. 88, supplement 2, pp. S133-S138, 2002.

[26] M. Franczyk-Zarów, R. B. Kostogrys, B. Szymczyk et al., "Functional effects of eggs, naturally enriched with conjugated linoleic acid, on the blood lipid profile, development of atherosclerosis and composition of atherosclerotic plaque in apolipoprotein $\mathrm{E}$ and low-density lipoprotein receptor double-knockout mice (apoE/LDLR-/-)," British Journal of Nutrition, vol. 99, no. 1, pp. 49-58, 2008.

[27] A. Koronowicz, K. Żwawa, B. Szymczyk, P. Pisulewski, and P. Laidler, "Wpływ lipidów żółtka jaja kurzego naturalnie wzbogaconego w izomery sprzężonego kwasu linolowego na proliferację komórek czerniaka ludzkiego," Bromatologia i Chemia Toksykologiczna, vol. 42, no. 3, pp. 1047-1051, 2009.

[28] G. Lu, G. Zhang, X. Zheng, Y. Zeng et al., "c9, t11- conjugated linoleic acid induces HCC cell apoptosis and correlation with PPAR- $\gamma$ signaling pathway," American Journal of Translational Research, vol. 7, no. 12, pp. 2752-2763, 2015.

[29] X. Wan, X. Yuan, X. Yang, Y. Li, and L. Zhong, "Studies on mechanism of cis9, trans11-CLA and trans10, cis12-CLA inducing apoptosis of human breast cancer cell line MCF-7," ChineseGerman Journal of Clinical Oncology, vol. 9, no. 10, pp. 583-589, 2010.

[30] N. S. Kelley, N. E. Hubbard, and K. L. Erickson, "Conjugated linoleic acid isomers and cancer," Journal of Nutrition, vol. 137, no. 12, pp. 2599-2607, 2007.

[31] H. Chujo, M. Yamasaki, S. Nou, N. Koyanagi, H. Tachibana, and K. Yamada, "Effect of conjugated linoleic acid isomers on growth factor-induced proliferation of human breast cancer cells," Cancer Letters, vol. 202, no. 1, pp. 81-87, 2003.

[32] K. L. Erickson and N. E. Hubbard, "Fatty acids and breast cancer: the role of stem cells," Prostaglandins Leukotrienes and Essential Fatty Acids, vol. 82, no. 4-6, pp. 237-241, 2010.

[33] P. Sertznig, M. Seifert, W. Tilgen, and J. Reichrath, "Present concepts and future outlook: function of peroxisome proliferatoractivated receptors (PPARs) for pathogenesis, progression, and therapy of cancer," Journal of Cellular Physiology, vol. 212, no. 1, pp. 1-12, 2007.

[34] J. Berger and D. E. Moller, "The mechanisms of action of PPARs," Annual Review of Medicine, vol. 53, pp. 409-435, 2002.

[35] A. Rogue, C. Spire, M. Brun, N. Claude, and A. Guillouzo, "Gene expression changes induced by PPAR gamma agonists in animal and human liver," PPAR Research, vol. 2010, Article ID 325183, 16 pages, 2010.

[36] M. Sokolowska, M. L. Kowalski, R. Pawliczak, and M. Sokołowska, "Peroxisome proliferator-activated receptors-g (PPAR-g ) and their role in immunoregulation and inflammation control," Postępy Higieny i Medycyny Doświadczalnej, vol. 59, pp. 472-484, 2005.

[37] B. Zhang, J. Berger, E. Hu et al., "Negative regulation of peroxisome proliferator-activated receptor- $\gamma$ gene expression 
contributes to the antiadipogenic effects of tumor necrosis factor- $\alpha$," Molecular Endocrinology, vol. 10, no. 11, pp. 1457-1466, 1996.

[38] X. Wang, Y. Sun, Y. Zhao et al., "Oroxyloside prevents dextran sulfate sodium-induced experimental colitis in mice by inhibiting NF- $\kappa \mathrm{B}$ pathway through PPAR $\gamma$ activation," Biochemical Pharmacology, vol. 106, pp. 70-81, 2016.

[39] N. Wieneke, K. I. Hirsch-Ernst, M. Kuna, S. Kersten, and G. P. Püschel, "PPAR $\alpha$-dependent induction of the energy homeostasis-regulating nuclear receptor NRli3 (CAR) in rat hepatocytes: potential role in starvation adaptation," FEBS Letters, vol. 581, no. 29, pp. 5617-5626, 2007.

[40] H. A. Burgess, L. E. Daugherty, T. H. Thatcher et al., "PPAR $\gamma$ agonists inhibit TGF- $\beta$ induced pulmonary myofibroblast differentiation and collagen production: implications for therapy of lung fibrosis," American Journal of Physiology_Lung Cellular and Molecular Physiology, vol. 288, no. 6, pp. L1146-L1153, 2005.

[41] M. Pignatelli, C. Cocca, A. Santos, and A. Perez-Castillo, "Enhancement of BRCA1 gene expression by the peroxisome proliferator-activated receptor $\gamma$ in the MCF-7 breast cancer cell line," Oncogene, vol. 22, no. 35, pp. 5446-5450, 2003.

[42] S. Y. Lee, G. Y. Hur, K. H. Jung et al., "PPAR- $\gamma$ agonist increase gefitinib's antitumor activity through PTEN expression," Lung Cancer, vol. 51, no. 3, pp. 297-301, 2006.

[43] Y.-M. Sue, C.-P. Chung, H. Lin et al., "PPAR $\delta$-mediated $\mathrm{p} 21 / \mathrm{p} 27$ induction via increased CREB-binding protein nuclear translocation in beraprost-induced antiproliferation of murine aortic smooth muscle cells," American Journal of PhysiologyCell Physiology, vol. 297, no. 2, pp. C321-C329, 2009.

[44] Z. Wu, E. D. Rosen, R. Brun et al., "Cross-regulation of $\mathrm{C} / \mathrm{EBP} \alpha$ and PPAR $\gamma$ controls the transcriptional pathway of adipogenesis and insulin sensitivity," Molecular Cell, vol. 3, no. 2, pp. 151-158, 1999.

[45] R. P. J. Oude Elferink and C. C. Paulusma, "Function and pathophysiological importance of ABCB4 (MDR3 P-glycoprotein)," Pflugers Archiv European Journal of Physiology, vol. 453, no. 5, pp. 601-610, 2007.

[46] M. Heim, J. Johnson, F. Boess et al., "Phytanic acid, a natural peroxisome proliferator-activated receptor (PPAR) agonist, regulates glucose metabolism in rat primary hepatocytes," The Federation of American Societies for Experimental Biology Journal, vol. 16, no. 7, pp. 718-720, 2002.

[47] V. Gburcik, N. Bot, M. Maggiolini, and D. Picard, "SPBP is a phosphoserine-specific repressor of estrogen receptor $\alpha$," Molecular and Cellular Biology, vol. 25, no. 9, pp. 3421-3430, 2005.

[48] S. Kouidhi, I. Seugnet, S. Decherf et al., "Peroxisome proliferator-activated receptor- $\gamma(\operatorname{PPAR} \gamma)$ modulates hypothalamic Trh regulation in vivo," Molecular and Cellular Endocrinology, vol. 317, no. 1-2, pp. 44-52, 2010.

[49] S. Sasaki, K. Kawai, Y. Honjo, and H. Nakamura, “Thyroid hormones and lipid metabolism," Nihon Rinsho. Japanese Journal of Clinical Medicine, vol. 64, no. 12, pp. 2323-2329, 2006.

[50] T. Miyamoto, A. Kaneko, T. Kakizawa et al., "Inhibition of peroxisome proliferator signaling pathways by thyroid hormone receptor. Competitive binding to the response element," Journal of Biological Chemistry, vol. 272, no. 12, pp. 7752-7758, 1997.

[51] A. Master and A. Nauman, "THRB (Thyroid Hormone Receptor, Beta)," Atlas of Genetics and Cytogenetics in Oncology and Haematology, vol. 18, no. 6, pp. 400-433, 2014.

[52] A. Master, A. Wójcicka, K. Giżewska, P. Popławski, G. R. Williams, and A. Nauman, "A novel method for gene-specific enhancement of protein translation by targeting $5^{\prime}$ UTRs of selected tumor suppressors," PLOS ONE, vol. 11, no. 5, Article ID e0155359, 2016.

[53] L. Al-Alem, R. C. Southard, M. W. Kilgore, and T. E. Curry, "Specific thiazolidinediones inhibit ovarian cancer cell line proliferation and cause cell cycle arrest in a PAR $\gamma$ independent manner," PLoS ONE, vol. 6, no. 1, Article ID e16179, 2011.

[54] C. Lu and S.-Y. Cheng, "Thyroid hormone receptors regulate adipogenesis and carcinogenesis via crosstalk signaling with peroxisome proliferator-activated receptors," Journal of Molecular Endocrinology, vol. 44, no. 3, pp. 143-154, 2010.

[55] L. Wang and Z.-Y. Wang, "The Wilms' tumor suppressor WT1 induces estrogen-independent growth and anti-estrogen insensitivity in ER-positive breast cancer MCF7 cells," Oncology Reports, vol. 23, no. 4, pp. 1109-1117, 2010.

[56] D. E. Zamora-Avila, P. Zapata-Benavides, M. A. Franco-Molina et al., "WT1 gene silencing by aerosol delivery of PEI-RNAi complexes inhibits B16-F10 lung metastases growth," Cancer Gene Therapy, vol. 16, no. 12, pp. 892-899, 2009.

[57] N. Wagner, J. Panelos, D. Massi, and K.-D. Wagner, "The Wilms' tumor suppressor WT1 is associated with melanoma proliferation," Pflügers Archiv-European Journal of Physiology, vol. 455, no. 5, pp. 839-847, 2008.

[58] P. Zapata-Benavides, M. Tuna, G. Lopez-Berestein, and A. M. Tari, "Downregulation of Wilms' tumor 1 protein inhibits breast cancer proliferation," Biochemical and Biophysical Research Communications, vol. 295, no. 4, pp. 784-790, 2002.

[59] G. Arpino, L. Wiechmann, C. K. Osborne, and R. Schiff, "Crosstalk between the estrogen receptor and the HER tyrosine kinase receptor family: molecular mechanism and clinical implications for endocrine therapy resistance," Endocrine Reviews, vol. 29, no. 2, pp. 217-233, 2008.

[60] R. I. Nicholson, I. R. Hutcheson, M. E. Harper et al., "Modulation of epidermal growth factor receptor in endocrine-resistant, oestrogen receptor-positive breast cancer," Endocrine-Related Cancer, vol. 8, no. 3, pp. 175-182, 2001.

[61] D. E. Zamora-Avila, M. A. Franco-Molina, L. M. TrejoAvila, C. Rodríguez-Padilla, D. Reséndez-Pérez, and P. ZapataBenavides, "RNAi silencing of the WT1 gene inhibits cell proliferation and induces apoptosis in the B16F10 murine melanoma cell line," Melanoma Research, vol. 17, no. 6, pp. 341348, 2007.

[62] J.-F. Michiels, C. Perrin, N. Leccia, D. Massi, P. Grimaldi, and N. Wagner, "PPARß activation inhibits melanoma cell proliferation involving repression of the Wilms' tumour suppressor WT1," Pflugers Archiv European Journal of Physiology, vol. 459, no. 5, pp. 689-703, 2010. 


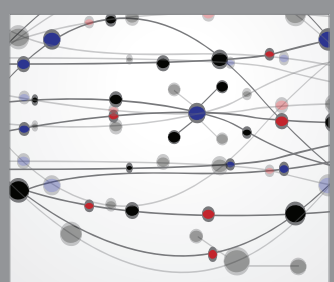

The Scientific World Journal
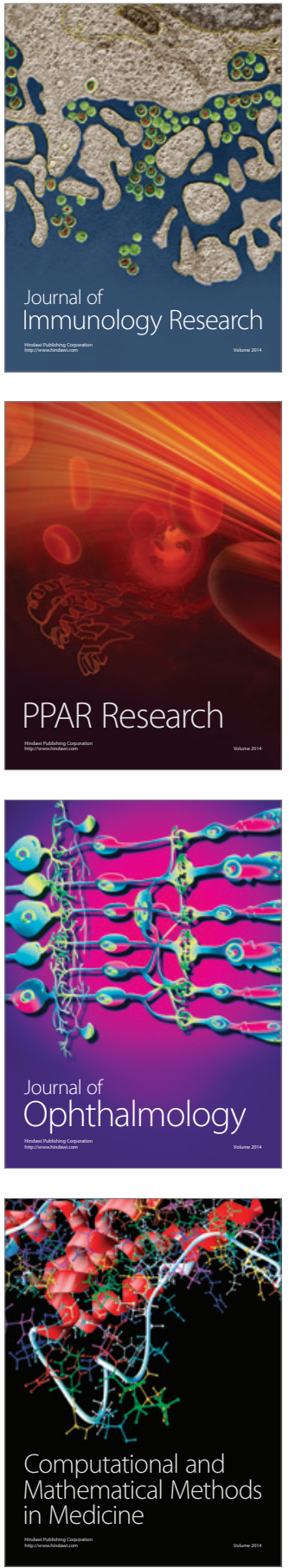

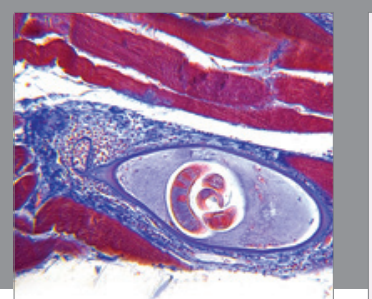

Gastroenterology Research and Practice
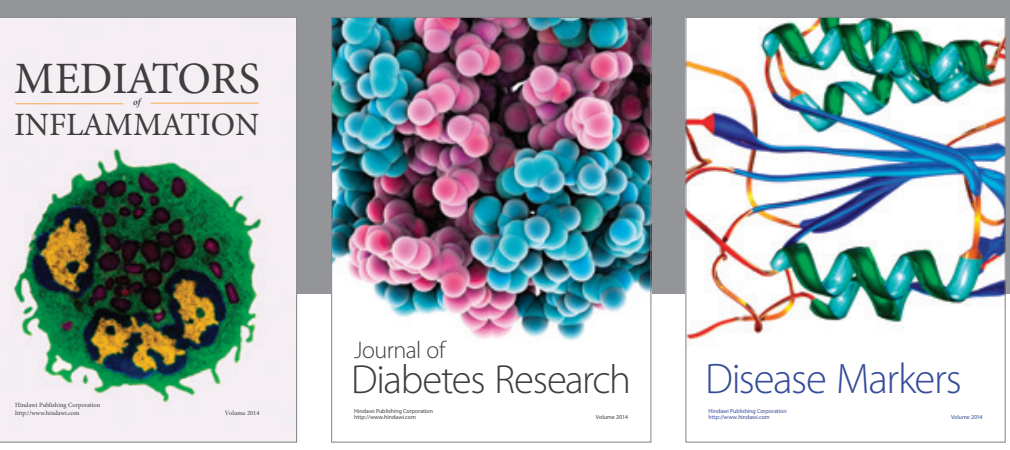

Disease Markers

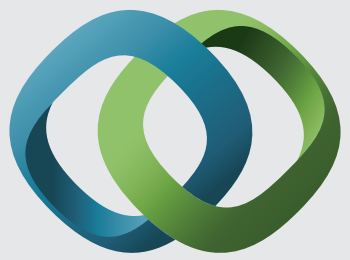

\section{Hindawi}

Submit your manuscripts at

https://www.hindawi.com
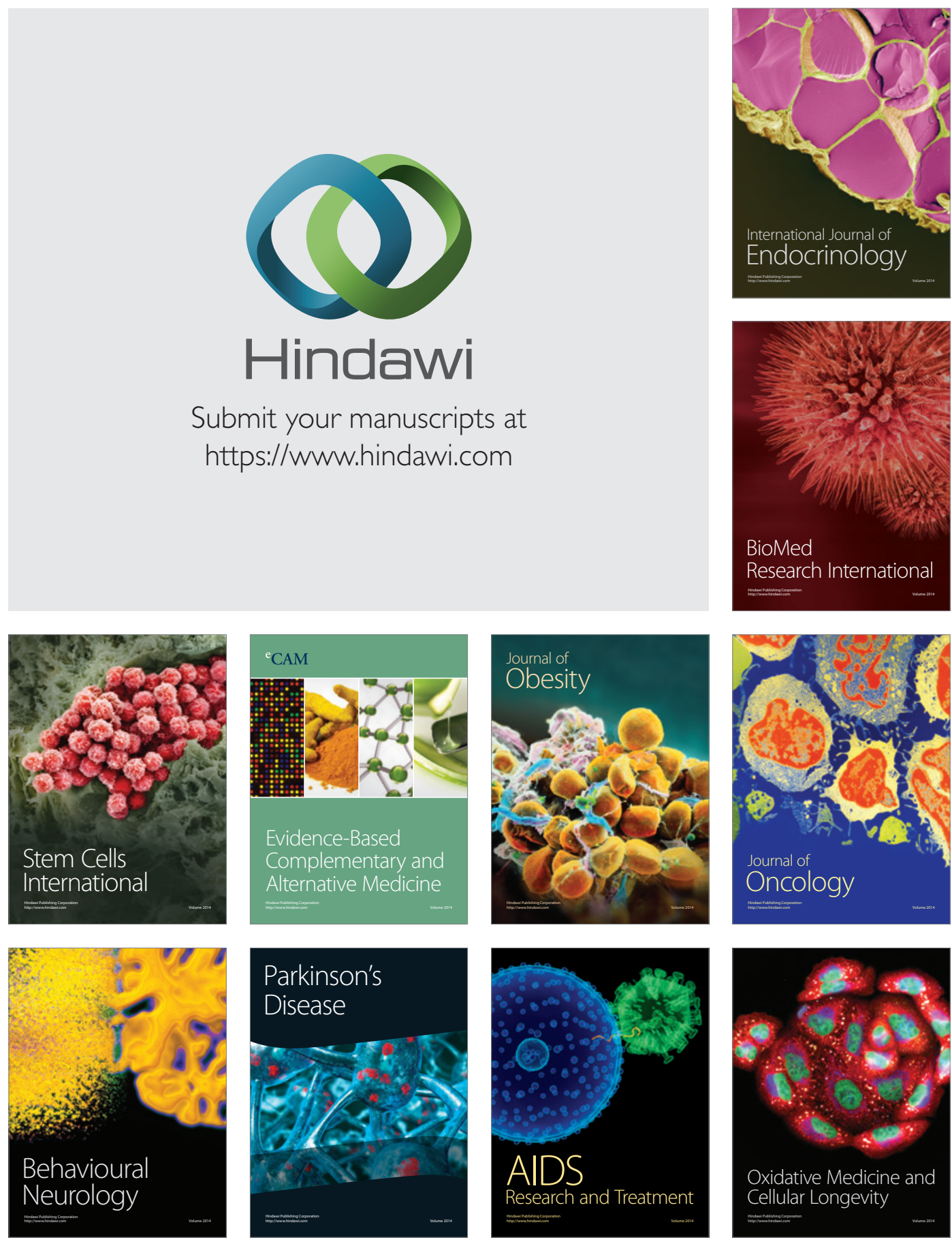